\title{
JOURNAL.RU
}

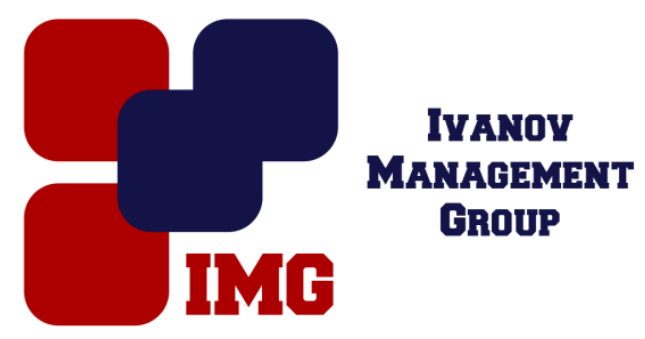

Запьянцев Д.С.

Тюменский государственный университет, Институт государства и права Тюмень, Россия

doi: 10.18411/1j-31-07-2017-41

idsp 000001:1j-31-07-2017-41

\section{Проблемы реализации принципа субсидиарности в организации и деятельности органов государственной власти субъектов Российской Федерации}

В последнее время в отечественной юридической науке конституционного права исследователями федерализма все чаще выдвигается идея реализации принципа субсидиарности как одного из конституционных принципов российского федерализма в качестве механизма при распределении публичной власти по вертикали и горизонтали. Так, например, по мнению В.П. Гаврилова «одним из направлений развития федерализма является последовательная реализация принципа субсидиарности, который должен рассматриваться в качестве исходного в разделении государственной власти между ее различными уровнями».

В данной статье мы не будем касаться становления принципа субсидиарности в теории публичного права т.к. на наш взгляд данный вопрос уже достаточно подробно исследован, а затронем основные проблемы реализации данного принципа как конституционно-правового на современном этапе развития федерализма в России.

Термин субсидиарность от латинского subsidiarius переводится как вспомогательный. Идея принципа субсидиарности состоит в том, чтобы передать государственно-властные полномочия на как можно более низкий уровень власти при котором возможна максимальная эффективность. В результате данный принцип предполагает передачу на уровень субъекта федерации максимально возможное количество полномочий, а федеральная 
власть должна выполнять только те функции и задачи, которые невозможно реализовать на уровне отдельно взятого субъекта. Безусловно при таком подходе взаимоотношений между федеральными органами государственной власти и органами государственной власти субъектов Российской Федерации необходимо на наш взгляд не только конституционно-правовое закрепление принципа субсидиарности, но и финансовая состоятельность субъектов Российской Федерации в противном случае полномочия попросту невозможно будет реализовать ввиду отсутствия денежных средств в бюджете региона, и принцип будет носить скорее декларативный характер, и не иметь практического применения.

Печальный опыт декларативности принципа федерализма на наш взгляд уже есть - это принцип равноправия субъектов Российской Федерации, который не только не соблюдается на практике, но и имеет определенные правовые коллизии. Так, например, ст. 5 Конституции Российской Федерации устанавливает 6 различных видов субъектов, если они равны между собой, то справедливо возникает вопрос - существует ли необходимость в такой сложной системе федеративного устройства? Большие вопросы вызывает и возможность республикам иметь свою конституции, а остальным субъектам Федерации свой устав.

Примеров таких правовых коллизий можно привести еще множество, поэтому очень важно подойти к реализации принципа субсидиарности, если это вообще возможно в текущих политических и экономических реалиях с особым вниманием.

Отечественные и зарубежные правоведы, исследуя федерализм по-разному трактуют понятие и содержание принципа субсидиарности в рамках конституционного права. Это объясняется тем, что принцип субсидиарности в настоящее время не закреплен ни в Конституции Российской Федерации, ни в каких-либо федеральных законах и является достаточно новым правовым явлением для отечественной юридической науки.

Зубрилина А.О. определяет принцип субсидиарности как «принцип, лежащий в основе распределения между акторами, находящимися на разных уровнях властной пирамиды, полномочий и компетенций, подразумевающий, когда это целесообразно, управление на возможно более низком уровне».

Калиниченко А.О. раскрывает данный принцип как «...принцип, предполагающий делегирование центральной государственной властью управленческих функций на уровень органов власти управления более низких 
территориальных единиц», и отмечает, что «Оптимальное распределение полномочий между федеральным центром и регионами (оптимальное соотношение централизации и децентрализации) - это постулат, в котором заключена основная цель принципа субсидиарности».

По мнению В.А. Жбанкова «Принцип субсидиарности, или принцип дополнительности, позволяет правовой системе избежать регулирования тех сфер, в которых право не может быть эффективно по своей природе и, с другой стороны, дает возможность «пользователям» - физическим и юридическим лицам - эффективно осуществлять контроль за качеством законодательной техники».

Загайнова Н.И. и Ларионова Н.И. исследуя возможность реализации модели конкурентного федерализма в России отмечают, что основополагающим принципом данной модели является принцип субсидиарности и определяет его сущность в том, что «задачи коллективных действий, в принципе, должны решаться на возможно более низком уровне власти».

Данный принцип отмечают исследователи положительно повлияет на развитие федеративных отношений между центром и регионами, отмечая положительный опыт его реализации в зарубежных федеративных государствах. В частности, принцип субсидиарности широко применяется в государствах Европы и имеет нормативно-правовое закрепление в Европейском Союзе в качестве одного из основных принципов. Так, например, 3.А. Духновская в своем диссертационном исследовании приходит к выводу, что «сравнительноправовое исследование законодательства европейских федеративных государств показывает, что в общим для них принципом распределения предметов ведения и полномочий является принцип субсидиарности».

Проанализировав научную литературу можно прийти к выводу, что большинство авторов поддерживают идею реализации принципа субсидиарности при взаимоотношениях органов публичной власти между собой и выделяют три основных признака характеризующих принцип:

- передача властных полномочий на как можно более близкий к обществу уровень власти;

- дополнительность;

- взаимопомощь.

Основополагающей характеристикой, по нашему мнению, является передача властных полномочий на как можно более близкий к обществу уровень власти. Т.е. принцип субсидиарности должен являться эффективным 
механизмом реализации конституционного принципа федерализма разграничения предметов ведения и полномочий между органами государственной власти Российской Федерации и органами государственной власти субъектов Российской Федерации.

Сиджански Д. справедливо замечает, что принцип субсидиарности «получил почти единогласную поддержку; такое редкое единогласие объясняется автором отсутствием точного определения его значения, что позволило каждому участнику вложить в него свой собственный смысл». Сыманюк Н.В. отмечает, что одной из проблем федеративной системы России является «появление так называемого федерального мандата, т.е. расширение полномочий за счет собственных бюджетов, которое особенно четко озвучивается Конституционным Судом РФ» и приходит к выводу, что «без достаточного финансирования это неизбежно ведет к увеличению социального бремени субъектов федерации и к неэффективному исполнению «спущенных» полномочий».

Трофимов Е.А. приходит к выводу, что «Игнорирование принципа субсидиарности нарушает существующую сегодня в России систему сдержек и противовесов, как по вертикали, так и по горизонтали».

По нашему мнению, основными препятствиями на пути к реализации принципа субсидиарности в Российской Федерации являются следующие:

- отсутствие правового закрепления принципа субсидиарности в Конституции Российской Федерации и федеральных законах;

- проблема самостоятельности субъектов Российской Федерации, заключающаяся как в чрезмерной централизации власти, так и в высокой бюджетной зависимости субъектов от финансовой помощи федеральных властей;

- политический фактор, заключающийся в нежелании федеральных властей к проведению федеративных реформ.

Как уже было сказано выше принцип субсидиарности не имеет своего конституционного закрепления поэтому, по нашему мнению, видится важным как минимум закрепить данный принцип в ст. 1 Федерального закона от 6 октября 1999 г. № 184-Ф3 «Об общих принципах организации законодательных (представительных) и исполнительных органов государственной власти субъектов Российской Федерации».

К сожалению, закрепить принцип субсидиарности не удастся в ст.5 Конституции Российской Федерации без пересмотра основ конституционного 
строя, однако решение проблемы возможно с помощью принятия специального федерального закона закрепляющего принципы федерализма в Российской Федерации в том числе и принцип субсидиарности, что также решит проблему классификации и содержания принципов федерализма в России т.к. исследователи выделяют различное количество принципов и проблема остается актуальной и в наши дни. Стоит отметить, что попыткой закрепить исчерпывающий перечень принципов федерализма была попытка в проекте Федерального закона № 96700167-2 «О принципах федерализма в России» от 3 декабря 1996 года.

Второй проблемой на пути реализации принципа субсидиарности является самостоятельность субъектов федерации, которая выражается как в распределении полномочий между федеральными органами государственной власти и органами государственной власти субъектов Российской Федерации по остаточному принципу, так и в экономической зависимости субъектов от федеральных властей. Стоит согласиться с мнением Д.А. Авдеева определяющего современное состояние федеративный отношений как: «...период определенной стагнации в развитии федеративных отношений, которые скорее можно охарактеризовать как «консервация» сложившегося в результате централистских мер «конституционного порядка», обусловленного социально-экономическими и политико-правовыми обстоятельствами и условиями».

Так, согласно статистике по данным Министерства Финансов Российской Федерации в 2011 году объем государственного долга субъектов Российской Федерации составлял 1.095 трлн. рублей, а по состоянию на 1 мая 2017 года 2.246 трлн. рублей. Всего за 6 лет совокупный долг субъектов федерации вырос более чем в 2 раза. Правительство пытается стабилизировать ситуацию сокращением бюджетных кредитов субъектам федерации, однако это будет компенсироваться увеличенным количеством дотаций регионам для выравнивания бюджетов. Как показал опыт прошлых лет «политика выравнивания» не оказалась эффективной в текущих реалиях, поэтому видится сомнительным эффект от такого шага и, по нашему мнению, не поменяет ситуацию коренным образом.

Принцип субсидиарности должен быть подкреплен стабильной финансовой базой субъектов Федерации т.е. в случае с данным принципом право должно следовать экономике, но не наоборот, когда правовая норма закреплена, а денежных средств не хватает на реализацию своих полномочий. 
Прежде всего для эффективной реализации принципа субсидиарности необходимы финансовые реформы и политическая воля федеральных властей.

Таким образом, по нашему мнению, в России еще не созданы условия для реализации принципа субсидиарности. Важным видится дальнейшее исследование принципа субсидиарности для того чтобы в будущем реализовать его на практике максимально эффективно т.к. на наш взгляд данный принцип является одним из ключевых принципов федерализма и наравне с принципом разграничения предметов ведения и полномочий между органами государственной власти Российской Федерации и органами государственной власти субъектов Российской Федерации, должен быть той скрепой, которая формирует российский федерализм. 
1. Авдеев Д.А. Проблемы и перспективы федерализма в России // Конституционноправовой статус субъекта Российской Федерации: современное состояние и перспективы: материалы межрегиональной научно-практической конференции, г. Тюмень, 18 сентября 2015 г. / под ред. канд. юрид. наук, доцента Д.А. Авдеева. - Тюмень: Издательство Тюменского государственного университета, 2016. - С. 9-17.

2. Баньковский А.Е. Конституционные принципы единства и субсидиарности в организации государственной власти в Российской Федерации: монография. Барнаул: Барнаульский юридический институт МВД России, 2016. - 160 с.

3. Гаврилов В.П. Становление федерализма в России // Федерализм. - 2014. - № 1. С. - 171182.

4. Государственный долг субъектов Российской Федерации и муниципальных образований [Электронный peсурс] // Минфин России [сайт]. URL: http://minfin.ru/ru/statistics/subbud/sub_debt/ (дата обращения: 31.05.2017).

5. Духновская 3.А. Исполнительная власть в Российской Федерации и федеративных государствах Европы: конституционно-правовое исследование: автореф. дис. ... канд. юрид. наук: 12.00.02. Российская академия народного хозяйства и государственной службы при Президенте Российской Федерации. Москва, 2012. - 25 с.

6. Жбанков В.А. Субсидиарность как свойство правовой системы // Вестник университета имени О.Е. Кутафина. - 2015. - № 5. - С. 43-50.

7. Загайнова Н.И., Ларионова Н.И. К вопросу методологии конкурентного федерализма // Вестник марийского государственного университета. - 2011. - № 6. - С. 191-195.

8. Зубрилина А.О. Субсидиарность в контексте федералистской теории // Философия права. - 2015. - № 5. - С. 91-96.

9. Калиниченко А.О. Проблемы реализации принципа субсидиарности в политической теории и практике // Академический вестник Ростовского филиала Российской таможенной академии. - 2016. - № 3. - С. 96-100.

10. Калиниченко А.О. Специфика реализации принципа субсидиарности в российском федерализме // Государственное и муниципальное управление. Ученые записки СКАГС. - 2016. - № 4. C. - 244-249.

11. Минфин впервые за несколько лет резко сократит бюджетные кредиты регионам [Электронный pecyp] http://www.rbc.ru/economics/01/11/2016/5818a1499a79474f30fafbfe (дата обращения: 31.05.2017).

12. Сиджански Д. Федералистское будущее Европы: от Европейского сообщества до Европейского Союза / перевод с франц. Т.М. Фадеева. - М.: Российский государственный гуманитарный университет, 1998. - 420 с.

13. Сыманюк Н.В. Порядок распределения компетенции в России и Германии // Конституционное и муниципальное право. - 2014. - № 2. - С. 35-39.

14. Трофимов Е.А. Принцип субсидиарности и эффективность российского федерализма // Государство и право: теория и практика: материалы Междунар. науч. конф. (г. Челябинск, апрель 2011 г.). - Челябинск: Два комсомольца, 2011. - С. 85-89. 